\title{
PHOTOLUMINESCENCE OF TETRANUCLEAR MERCURY(II) COMPLEXES
}

\author{
H. KUNKELY and A. VOGLER \\ Institut für Anorganische Chemie, Universität Regensburg, Universitätsstrasse 31, \\ D-8400 Regensburg, Federal Republic of Germany
}

Received 20 September 1989

\begin{abstract}
The complexes $\left[\mathrm{Hg}_{4}(\mathrm{SPh})_{6}\left(\mathrm{PPh}_{3}\right)_{4}\right]^{2+}$ and $[\mathrm{Hg}(2 \text {-pyridylphenyl) }) \mathrm{Cl}]_{4}$ show an intense low-temperature (77 K) phosphorescence at $\lambda_{\max }=690$ and $500 \mathrm{~nm}$. This cmission is assumcd to originate from a metal-centered ds excited state which contains considerable ligand-to-metal charge transfer character.
\end{abstract}

\section{Introduction}

In recent years we have observed photoluminescence from tetrameric $\mathrm{Cu}(\mathrm{I})$ [1], $\mathrm{Ag}(\mathrm{I})$ [2], and $\mathrm{Au}(\mathrm{I})$ [3] clusters in solution or low-temperature glasses. In addition, emission from dimeric Au(I) complexes was reported by other groups $[4,5]$. We assigned the luminescence of the tetramers to metalcentered $\mathrm{s} \rightarrow \mathrm{d}$ transitions which are modified by metal-metal interaction in these $d^{10}$ clusters [1-3]

Other important $\mathbf{d}^{10}$ metal ions are those of the IIb group ( $\left.\mathrm{Zn}^{2+}, \mathrm{Cd}^{2+}, \mathrm{Hg}^{2+}\right)$. While semiconductors such as $\mathrm{ZnS}, \mathrm{CdS}[6,7]$, and $\mathrm{HgI}_{2}$ [8-10] are well known to show photoluminescence, any emission from the $\mathbf{M}^{2+}$ ions or their molecular complexes $\# 1$ has not been reported to our knowledge. It was even stated that a characteristic emission from $\mathrm{Hg}$ (II) is unlikely $[12]$. However, in analogy to $\mathrm{Cu}(\mathrm{I}), \mathrm{Ag}(\mathrm{I})$, and $\mathrm{Au}$ (I) we anticipated that $\mathrm{Hg}$ (II) clusters might be luminescent, too. This expectation was based on the fact that the energy separation between the $n \mathrm{~d}^{10}$ and $n \mathrm{~d}^{9}(n+1) \mathrm{s}^{1}$ configuration of $\mathrm{Hg}^{2+}(\approx 43000$ $\left.\mathrm{cm}^{-1}\right)$ is very similar to that of $\mathrm{Ag}^{+}\left(\approx 39000 \mathrm{~cm}^{-1}\right)$ [13]. For the present study we chose the complexes $\left[\mathrm{Hg}(\right.$ pyph $) \mathrm{Cl}_{4}$ [14] with pyph=2-pyridylphenyl and $\left[\mathrm{Hg}_{4}(\mathrm{SPh})_{6}\left(\mathrm{PPh}_{3}\right)_{4}\right]^{2+}[15]$ with $\mathrm{Ph}=$ phenyl as suitable $\mathrm{Hg}(\mathrm{II})$ clusters.

\#1 Luminescence originating from ligands which are coordinated $10 \mathrm{M}^{2+}$ ions is well known. For example, porphyrin complexes of $\mathrm{Zn}^{2+}$ show the typical porphyrin emission [11].

\section{Experimental}

The compounds $\left[\mathrm{Hg}(\mathrm{pyph}) \mathrm{Cl}_{4} \quad[14]\right.$, $\left[\mathrm{Hg}_{4}(\mathrm{SPh})_{6}\left(\mathrm{PPh}_{3}\right)_{4}\right]\left(\mathrm{ClO}_{4}\right)_{2}[15],\left[\mathrm{Hg}\left(\mathrm{PPh}_{3}\right)_{2}\right]-$ $\left(\mathrm{ClO}_{4}\right)_{2}[16]$, and $\left[\mathrm{Hg}(\mathrm{SPh})_{2}\right]$ [15] were prepared according to published procedures. The complex ion $\left[\mathrm{Hg}_{4}(\mathrm{SPh})_{6}\left(\mathrm{PPh}_{3}\right)_{4}\right]^{2+}$ underwent a slow decomposition in solution and in the solid state. The spectral measurements of this ion were carried out only with freshly prepared samples. Absorption spectra were measured in solution at room temperature on a Uvikon 860 absorption spectrometer. Emission spectra of the complexes in the solid state or in glasses of ethanol or $\mathrm{CH}_{2} \mathrm{Cl}_{2}$ /toluene $(1: 1)$ were obtained on a Hitachi 850 spectrofluorimeter equipped with a Hamamatsu 928 photomultiplier. The luminescence spectra were corrected for monochromator and photomultiplier efficiency.

\section{Results}

The absorption spectrum of $[\mathrm{Hg}(\text { pyph }) \mathrm{Cl}]_{4}$ (fig. 1) shows two bands at $\lambda_{\max }=242 \mathrm{~nm}(\epsilon=160000)$ and $275 \mathrm{~nm} \quad(\epsilon=120000)$. The complex ion $\left[\mathrm{Hg}_{4}(\mathrm{SPh})_{6}\left(\mathrm{PPh}_{3}\right)_{4}\right]^{2+}$ does not absorb above 400 $\mathrm{nm}$ (fig. 2). Besides a shoulder at $325 \mathrm{~nm}$ $(\epsilon=12700)$, the spectrum is rather featureless. Below $250 \mathrm{~nm}$ it could not be recorded due to the cut off by the solvent. At room temperature both complexes did not show any photoemission. However, at 


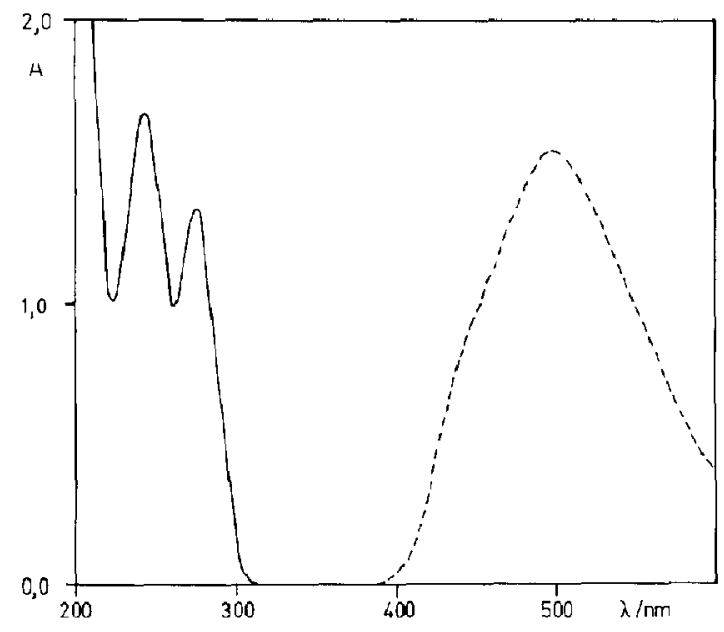

Fig. 1. Electronic absorption (-) and emission (---) spectra of $[\mathrm{Hg} \text { (2-pyridylphenyl) } \mathrm{Cl}]_{4}$. Absorption: $1.1 \times 10^{-5} \mathrm{M}$ in EtOH at room temperature, $1 \mathrm{~cm}$ cell. Emission: in $\mathrm{EtOH}$ at $77 \mathrm{~K}$; $\lambda_{\mathrm{exc}}=340 \mathrm{~nm}$, intensity in arbitrary units.

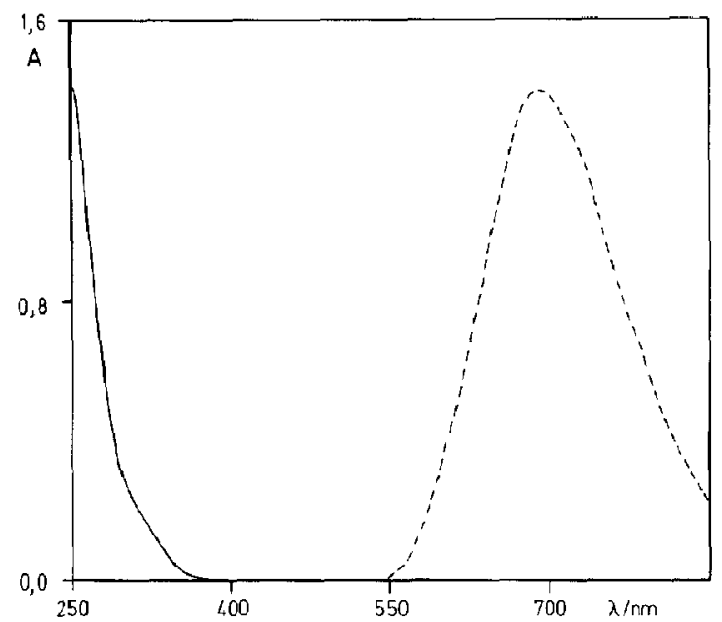

Fig. 2. Electronic absorption (-) and emission (--) spectra of $\left[\mathrm{Hg}_{4}(\mathrm{SPh})_{6}\left(\mathrm{PPh}_{3}\right)_{4}\right]\left(\mathrm{ClO}_{4}\right)_{2}$. Absorption: $1.02 \times 10^{-5} \mathrm{M}$ in methylene chloride at room temperature, $1 \mathrm{~cm}$ cell. Emission: in methylene chloride/toluene at $77 \mathrm{~K} ; \lambda_{\mathrm{exc}}=330 \mathrm{~nm}$, intensity in arbitrary units.

$77 \mathrm{~K}$ they cmitted strongly. The luminescence was independent of the exciting wayelength within the absorption range of the complexes. An emission by impurities can thus be excluded. The intense green luminescence of $[\mathrm{Hg}(\text { pyph }) \mathrm{Cl}]_{4}$ (fig. 1) appeared in the solid state and in glasses of toluene or ethanol $\left(\lambda_{\max }=500 \mathrm{~nm}\right)$. The strong red emission of
$\left[\mathrm{Hg}_{4}(\mathrm{SPh})_{6}\left(\mathrm{PPh}_{3}\right)_{4}\right]^{2+}$ (fig. 2) was observed for the solid perchlorate and in glasses of $\mathrm{CH}_{2} \mathrm{Cl}_{2} /$ toluene $\left(\lambda_{\max }=690 \mathrm{~nm}\right)$. For comparison we searched also for an emission of $\left[\mathrm{Hg}(\mathrm{SPh})_{2}\right]$ and $\left[\mathrm{Hg}(\mathrm{PPh})_{2}\right] \quad\left(\mathrm{ClO}_{4}\right)_{2}$. Under comparable conditions $\left[\mathrm{Hg}(\mathrm{SPh})_{2}\right]$ did not emit at all while the cation $\left[\mathrm{Hg}\left(\mathrm{PPh}_{3}\right)_{2}\right]^{2+}$ showed a green luminescence $\left(\lambda_{\max }=490 \mathrm{~nm}\right)$. This emission seems to be associated with the coordinated $\mathrm{PPh}_{3}$ ligand [17].

\section{Discussion}

The structure of $[\mathrm{Hg}(\mathrm{pyph}) \mathrm{Cl}]_{4}$ consists of a rectangle of four $\mathrm{Hg}$ (II) ions which are bridged by chloride ligands [14]. In addition, the tetrameric complex contains four ortho-metallated 2-pyridylphenyl ligands. The cation $\left[\mathrm{Hg}_{4}(\mathrm{SPh})_{6}\left(\mathrm{PPh}_{3}\right)_{4}\right]^{2+}$ contains a $\mathrm{Hg}_{4} \mathrm{~S}_{6}$ adamantane core [15]. Four $\mathrm{Hg}(\mathrm{II})$ ions form a tetrahedron. Its edges are bridged by six phenylthiolate ligands. Four $\mathrm{PPh}_{3}$ ligands are coordinated terminally to mercury. With regard to the ligands each $\mathrm{Hg}$ (II) has roughly a tetrahedral environment.

It is assumed that in these $\mathrm{Hg}(\mathrm{II})_{4}$ clusters there is some metal-metal bonding which is caused by ds orbital mixing in analogy to tetrameric $\mathrm{Cu}(\mathrm{I}), \mathrm{Ag}(\mathrm{I})$, and $\mathrm{Au}(\mathrm{I})$ complexes [1-3]. This assumption is based on several considerations. First, the ds energy separation of $\mathrm{Hg}(\mathrm{II})$ is not much larger that that of $\mathrm{Ag}$ (I) [13]. Secondly, ds mixing is known to occur not only in many mononuclear $\mathrm{Cu}(\mathrm{I}), \mathrm{Ag}(\mathrm{I})$, and $\mathrm{Au}$ (I) complexes but also in corresponding $\mathrm{Hg}$ (II) compounds $[13,18]$. These $\mathrm{d}^{10}$ ions might be expected to form only highly symmetric complexes with tetrahedral or octahedral structures. However, these metals prefer frequently linear complexes which are stabilized by ds mixing (second-order Jahn-Teller effect). Consequently, this tendency of $\mathrm{Hg}$ (II) to utilize ds mixing seems to be the origin of cluster formation by forming weak metal-metal bonds in the ground state. In this context it is quite interesting that the presence of attractive forces between $\mathrm{d}^{10}$ ions including $\mathrm{Hg}$ (II) seems to be a very general phenomenon $[19,20]$.

The absorption and particularly the emission spectra can now be used to probe the metal-metal interaction in the $\mathrm{Hg}(\mathrm{II})_{4}$ clusters. The absorption 
spectra of $\mathrm{HgX}_{2}$ and $\left[\mathrm{HgX}_{4}\right]^{2-}\left(\mathrm{X}^{-}=\right.$halide $)$contain long-wavelength bands in the UV which have been generally assigned to ligand to metal charge transfer (LMCT) transitions involving the promotion of a ligand electron to the $6 \mathrm{~s}(\mathrm{Hg})$ orbital [2125 ]. However, it has been also suggested that this transition may contain a considerable contribution from the lowest $5 \mathrm{~d} \rightarrow 6 \mathrm{~s}$ transition as pointed out by Jørgensen [26]. There is indeed evidence that the 5d orbitals of mercury are really valence orbitals which are certainly not too low to participate in electronic transitions at reasonable energies. This is supported by the observation that $\mathrm{Hg}$ (II) can be electrochemically oxidized to $\mathrm{Hg}$ (II) at low temperatures [27]. Also for the complexes of other $\mathrm{d}^{10}$ ions such as $\mathrm{Cu}(\mathrm{I})$ and $\mathrm{Ag}(\mathrm{I})$ the ds transitions should contain some LMC'T character [28]. This is also apparent from the spectra of $\mathrm{Ag}^{+}$in matrices of alkali halides. The ds transitions of $\mathrm{Ag}^{+}$undergo a considerable red shift in the series halide $=\mathrm{Cl}^{-}, \mathrm{Br}^{-}$and iodide [29]. Such a shift is expected for LMCT transitions.

According to these considerations we suggest that the longest-wavelength absorption of $\left[\mathrm{Hg}_{4}(\mathrm{SPh})_{6}\right.$ $\left.\left(\mathrm{PPh}_{3}\right)_{4}\right]^{2+}$ at $325 \mathrm{~nm}$ is assigned to a mixture of the metal-centered $5 \mathrm{~d} \rightarrow 6 \mathrm{~s}$ and a LMCT (thiolate $\rightarrow 6 \mathrm{~s}$ ) transition which is somewhat modified by ds orbital mixing in analogy to the metal-metal interaction in $\mathrm{Cu}(\mathrm{I}), \mathrm{Ag}(\mathrm{I})$, and $\mathrm{Au}(\mathrm{I})$ clusters [1-3]. Any participation of the mercury $6 \mathrm{p}$ orbitals can certainly be excluded since they occur at extremely high energies. The electron configuration $5 \mathrm{~d}^{9} 6 \mathrm{p}^{1}$ is locatcd approximately $119000 \mathrm{~cm}^{-1}$ above the $5 \mathrm{~d}^{10}$ ground statc [13]. The strong absorptions of $\left[\mathrm{Ig}(\mathrm{SRh})_{6^{-}}\right.$ $\left.\left(\mathrm{PPh}_{3}\right)_{4}\right]^{2+}$ toward shorter wavelength are most likely associated with the $\pi \pi^{*}$ excitation of the ligand phenyl groups.

In the case of $[\mathrm{Hg}(\mathrm{pyph}) \mathrm{Cl}]_{4}$ the ligands are less reducing. The ds/LMCT transitions are thus expected to occur at higher energies. However, such bands were not detected since the spectrum (fig. 1) is dominated by the intense intraligand (IL) bands of the ortho-metallated pyph ligand at 275 and 242 $\mathrm{nm}$. At very similar energies these IL bands appear also in the spectra of other pyph complexes [30,31].

Both tetranuclear mercury complexes show a very strong low-temperature luminescence in the visible region. The red emission of $\left[\mathrm{Hg}_{4}(\mathrm{SPh})_{6}\left(\mathrm{PPh}_{3}\right)_{4}\right]^{2+}$ appears at $690 \mathrm{~nm}$ and the green luminescence of
$[\mathrm{Hg}(\text { pyph }) \mathrm{Cl}]_{4}$ at $500 \mathrm{~nm}$. These emissions cannot be attributed to IL transitions which should be observed at shorter wavelength. The IL emission of $\left[\mathrm{Hg}\left(\mathrm{PPh}_{3}\right)_{2}\right]^{2+}$ occurs at $490 \mathrm{~nm}$. This is comparable to the IL emissions of other $\mathrm{PPh}_{3}$ complexes [17]. The IL phosphorescence of the coordinated pyph ligand appears at $\approx 450 \mathrm{~nm}[30,31]$. At low temperatures it shows also a well-resolved vibrational structure which is not apparent in the luminescence spectrum of $[\mathrm{Hg}(\mathrm{pyph}) \mathrm{Cl}]_{4}$ ( fig. 1).

We suggest that the basic features of the luminescence of the $\mathrm{Hg}(\mathrm{II})_{4}$ clusters can be explained in analogy to the tetramers of $\mathrm{Cu}(\mathrm{I}), \mathrm{Ag}(\mathrm{I})$, and $\mathrm{Au}(\mathrm{I})$ [1-3]. The $d$ and $s$ valence orbitals are split into bonding, nonbonding, and antibonding orbitals by metal-metal interaction. The lowest-energy ds excited state is thus associated with a contraction of the metal cluster due to increased metal-metal bonding. As a consequence the corresponding emission from the ds excited state undergoes a rather large Stokes shift. As discussed above the ds transition may contain an LMCT contribution. This contribution could be smaller for $\mathrm{Cu}(\mathrm{I}), \mathrm{Ag}(\mathrm{I})$, and $\mathrm{Au}(\mathrm{I})$ and larger for $\mathrm{Hg}$ (II). But the basic features of the emission would not be much different. A pure low-energy LMCT transition leads also to the population of a metal-metal bonding $\mathrm{MO}$ of $6 \mathrm{~s}$ origin and subsequently to a contraction of the cluster.

The luminescence of the $\mathrm{Hg}(\mathrm{II})_{4}$ clusters should be a phosphorescence which is assigned to a spin-forbidden triplet-singlet transition. However, due to the very strong spin-orbit coupling of such a heavy metal the spin selection rule may be only of limited value.

\section{Acknowledgement}

Support of this research by the Deutsche Forschungsgemeinschaft is gratefully acknowledged.

\section{References}

[1] A. Vogler and H. Kunkely, J. Am. Chem. Soc. 108 (1986) 7211.

[2] A. Vogler and H. Kunkely, Chem. Phys. Letters 158 (1989) 74.

[3] A. Vogler and H. Kunkely, Chem. Phys. Letters 150 (1988) 135. 
[4] Md.N.J. Khan, J.P. Fackler Jr., C. King, J.C. Wang and S. Wang, Inorg. Chem. 27 (1988) 1672; C. King, J.-C. Wang, Md.N.I, Khan and J.P. Fackler Jr,, Inorg. Chem. 28 (1989) 2145.

[5] C.-M. Che, W.-T. Wong, T.-F. Lai and H.-L. Kwong, J. Chem. Soc. Chem. Commun. (1989) 243;

C.-M. Che, H.-L. Kwong, V.W.-W. Yam and K.-C. Cho, J. Chem. Soc. Chem. Commun. (1989) 885.

[6] S. Shionoya, in: Luminescence of inorganic solids, ed. P. Goldberg (Academic Press, New York, 1966) p. 206.

[7] A. Henglein, Topics Current Chem. 143 (1988) 113.

[8] T. Goto, K. Nakaoka and Y. Nishina, J. Luminescence $12 /$ 13 (1976) 599.

[9] G. Kurtze, C. Klingshirn, B. Hönerlage, E. Tomzig and H. Scholz, J. Luminescence 20 (1979) 151.

[10] Z.L. Wu, J.L. Merz, L. van den Berg and W.F. Schnepple, J. Luminescence 24/25 (1981) 197.

[11] M. Gouterman, in: The porphyrins, Vol. 3, part A, ed. D. Dolphin (Academic Press, New York, 1978) p. 1.

[12] G. Blasse and G.P.M. van den Heuvel, J. Luminescence 9 (1974) 74.

[13] L.E. Orgel, J. Chem. Soc. (1958) 4186.

[14] E.C. Constable, T.A. Leese and D.A. Tucher, J. Chem. Soc. Chem. Commun. (1989) 570.

[15] P.A.W. Dean, J.-J. Vittal and M.H. Trattner, Inorg. Chem. 26 (1987) 4245

[16] T. Allman and R.G. Goel, Can. J. Chem. 62 (1984) 621.

[17] D.P. Segers, M.K. DeArmond, P.A. Grutsch and C. Kutal, Inorg. Chem. 23 (1984) 2874.

[18] C.K. Jørgensen, Modern aspects of ligand field theory (North-Holland, Amsterdam, 1971 ) p. 404.

[19] P.K. Mehrotra and R. Hoffmann, Inorg. Chem. 17 (1978) 2187

Y. Jian, S. Alvarez and R. Hoffmann, Inorg. Chem. 24 (1985) 749;
K.M. Merz Jr. and R. Hoffmann, Inorg. Chem. 27 (1988) 2120 .

[20] II. Schmidbauer, W. Graf and G. Müller, Angew. Chem. Intern. Ed. Engl. 27 (1988) 417;

H. Schmidbauer, K. Dziwok, A. Grohmann and G. Müller, Chem. Ber. 122 (1989) 893, and references therein

[21] P. Templet, J.R. McDonald, S.P. McGlynn, C.H. Kendrow, J.L. Rocbber and K. Weiss, J. Chem. Phys. 56 (1972) 5746.

[22] M.E. Koutek and W.R. Mason, Inorg. Chem. 19 (1980) 648.

[23] S. Sakaki, N. Hagiwara, N. Iwasaki and A. Ohyoshi, Bull. Chem. Soc. Japan 50 (1977) 14.

[24] R.A. Walton, R.W. Matthews and C.K. Jørgensen, Inorg. Chim. Acta 1 (1967) 355.

[25] P. Day and R.H. Seal, J. Chem. Soc. Dalton Trans. (1972) 2054.

[26] C.K. Jorgensen, Modern aspects of ligand field theory (North-Holland, Amsterdam, 1971 ) p. 398.

[27] R.L. Deming, A.L. Allred, A.R. Dahl, A.W. Herlinger and M.O. Kestner, J. Am. Chem. Soc. 98 (1976) 4132.

[28 ] C.K. Jørgensen, Solid State Phys. 13 (1962) 375; Oxidation numbers and oxidation states (Springer, Berlin, 1969) p. 128.

[29] K. Fussgaenger, W. Martienssen and H. Bilz, Phys. Stat. Sol. 12 (1965) 383.

[30] V. Balzani, M. Maestri, A. Melandri, D. Sandrini, L. Chassot, C. Corniolcy-Depuschel, P. Jollict, U, Maeder and A, von Zelewsky, in: Photochemistry and photophysics of coordination compounds, eds. H. Yersin and A. Vogler (Springer, Berlin, 1987) p. 71;

L. Chassot, A. von Zelewsky, D. Sandrini, M. Maestri and V. Balzani, J. Am. Chem. Soc. 108 (1986) 6084.

[31] S. Sprouse, K.A. King, P.J. Spellane and R.J. Watts, J. Am. Chem. Soc. 106 (1984) 6647. 